\title{
新鮮な花崗岩および破砕花崗岩中におけるセシウムの移行
}

\author{
岩井孝幸*1・雨貝信治*2・中山真一*3
}

\section{Migration Behavior of Cesium in Fresh and Fractured Granite}

\author{
Takayuki IWAI ${ }^{* 1}$, Shinji AMAGAI ${ }^{* 2}$ and Shinichi NAKAYAMA*3
}

Key words : セシウム cesium, 移行 migration, 収着 sorption, 花崗岩 granite.

\begin{abstract}
Sorption of radionuclides on fractured rocks are of importance to understand the migration behavior in crystalline rocks such as granite, in which fractured zones are likely to be major migration paths. In the present study, sorption of cesium on fractured granite was measured by batch and column sorption experiments, and compared with that on fresh granite.

The distribution coefficients for fractured granite, obtained by the batch sorption experiments, were one to two orders in magnitude larger than those for fresh granite. The larger sorption in fractured zones implies that migration of elements in fractured zones could not be as significant as that expected by the higher groundwater velocity. The cesium migration through fresh granite-packed columns could be described by one-dimensional advection-dispersion equation, in which sorption equilibrium was attained.
\end{abstract}

\section{はじめに}

使用済み核燃料の再処理から発生する高レベル放射性 廃棄物の処分法として, 地下深部岩体中への永久処分が 考えられている。その処分施設へ地下水が浸入すると， 廃棄物固化体から放射性核種が溶出し, 地層中の割れ目 等を通り人間環境に移行する可能性がある。この放射性 核種の移行は, 天然バリア（地層）と人工バリア（固化 体, 容器, 緩衝材等) とからなる多重バリアシステムに よって阻止あるいは遅延されると考えられている。 国内には広範囲に花崗岩が存在し，この岩体中が処分

*1 懒熊谷組技術研究所 Institute of Construction Technology, Kumagai Gumi Co., Ltd.

*2 東亜建設工業(侏) 大阪支店 Toa Corporation, Oosaka.

*3 日本原子力研究所 環境安全研究部 Department of Environmental Safety Research, JAERI.
場の対象となるならば, 花崗岩が天然バリアとなる。花 崗岩には地殼変動によって生じた断層などの割れ目があ り,これらは断裂や圧砕などの作用により破砕帯を形成 していることがある。割れ目内は, 周辺岩盤中に比べて 地下水の流速が速いので, 割れ目が核種の主たる移行経 路になる。したがって, このような破砕帯中の花崗岩 (破砕花崗岩) の収着（吸着十吸収）特性を調べ, 新鮮 な花崗岩に対する核種移行特性と比較検討することは重 要である。

高レベル放射性廃棄物の中では, セシウム -137 $\left({ }^{137} \mathrm{Cs}\right)$ およびストロンチウム $-90\left({ }^{90} \mathrm{Sr}\right)$ が重要な核 種である。これらの核種は, 再処理直後の軽水炉ウラン 燃料に含まれる核分裂生成物の放射能の $8 \%$ を占め, 再処理後 100 年では $98 \%$ を占めるようになる ${ }^{5)}$ 。 $\mathrm{Cs}, \mathrm{Sr}$ については, 土壌, 砂や粘土中における移行特

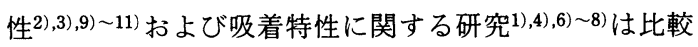


的多い。しかし，岩石を対象とした研究は少なく12) 14)， 破砕帯中の岩石と新鮮な岩石とに関して, 核種移行の遅 延効果を比較検討した報告はさらに少ない。

本研究では, 破砕花崗岩が持つ Cs の保持能力および それに起因する遅延効果について基礎的な知見を得る目 的で, 新鮮な花崗岩と破砕花崗岩に対して実験を行っ た。まず，純水と地下水を使用したバッチ実験から破砕 花崗岩の吸着特性を求め, この結果を確認するために, 純水および模擬廃棄物ガラス固化体からの浸出液を使用 したカラム実験を行い，比較検討した。

\section{1. 核種移行特性の評価手法}

天然バリア中を移行する核種を遅延させる要因には, 収着, 岩石および間隙中への拡散, 万過, 沈澱, 化学的 置換等がある14)。収着にはイオン交換による吸着, 錯 生成による吸着, 物理的吸着等があり, $\mathrm{Cs}^{+}, \mathrm{Sr}^{2+}$, $\mathrm{Co}^{2+}$ などの陽イオンは, 主としてイオン交換反応によ り, 吸着, 脱着を繰り返しながら移行すると考えられて いる6)。

遅延を表す指標として，Retardation factor $\left(R_{f}\right.$ : 遅延 係数）がよく用いられる。これは，水の移動速度に対す る核種の移動速度の比として定義される。すなわち, 破 砕帯内の水の速度を $v_{\mathrm{w}}$ とすれば，核種の実験の移動速 度は $v_{\mathrm{w}} / R_{f}$ である。また, 収着の反応が可逆的で, その 反応が平衡状態に達している場合の, 固相側への吸着量 と液相側への残存量の比，すなわちDistribution coefficient ( $K d$ : 分配係数) を用いて, 核種移行特性を 定量化することもできる。後述するように，これら 2 つの值は結び付けることができる。

$K d$ および $R_{f}$ を求める代表的実験手法は, それぞれ バッチ法およびカラム法である。バッチ法では, 対象核 種を含んだ溶液中に一定量の岩石粒を入れ，岩石への収 着量等から $K d$ を求める。カラム法では岩石粒（あるい は岩石コア）をカラムに詰めて, 溶液を瞬間あるいは連 続注入することにより, 対象核種の岩石粒中における移 動速度等から $R_{f}$ を求め, $R_{f}$ から $K d$ を算出する。ここ

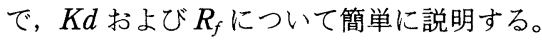

(1) 分配係数 $(K d)$ と分配比 $(R d)$

固相への収着が可逆的な反応のみにより起こり，それ が平衡に達していることが確認された場合,

固相中の核種濃度 $(\mathrm{Ci} / \mathrm{g}) /$

$$
\text { 液相中の核種濃度 }(\mathrm{Ci} / \mathrm{m} l)
$$

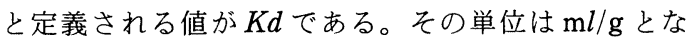
る。上記の条件が確認されない場合は Distribution ratio ( $R d$ ：分配比）として表す ${ }^{14)}$ 。これらの值は，核
種と岩石の種類だけでなく, 共存イオン6),7), $\mathrm{pH}^{8)}$, 核 種の濃度, 温度等の影響を受け, また平衡濃度までの到 達時間も異なる ${ }^{4), 13), 14), 16) 。 ~}$

(2) 遅延係数 $\left(R_{f}\right)$

前述したように， $R_{f}$ は次式で定義される。

$$
R_{f}=T_{\mathrm{t}} / T_{\mathrm{w}}=v_{\mathrm{w}} / v_{\mathrm{t}}
$$

$$
\begin{gathered}
\text { ここに } T_{\mathrm{w}}: \text { ある距離 } L \text { に対する水の到達時間 } \\
T_{\mathrm{t}}: \text { 距離 } L \text { に対する核種の到達時間 } \\
v_{\mathrm{w}}: \text { 水の速度 } \\
v_{\mathrm{t}}: \text { 核種の速度 }
\end{gathered}
$$

平衡時の液相および固相中の核種の濃度 $C_{\mathrm{w}}$ および $C_{\text {sd }}$ は

$$
C_{\mathrm{w}}=a_{\mathrm{w}} / V_{\mathrm{w}} \quad \text { および } \quad C_{\mathrm{sd}}=a_{\mathrm{s}} / M_{\mathrm{s}}
$$

ここに $a_{\mathrm{w}}$ : 液相中の核種の量 $\quad V_{\mathrm{w}}$ : 液相の体積 $a_{\mathrm{s}}:$ 固相中の核種の量 $\quad M_{\mathrm{s}}$ : 固相の体積 となる。平衡時におけるカラム内の $a_{\mathrm{w}}, a_{\mathrm{s}}$ は, それぞれ 核種の液相中の容量および固相の吸着容量を意味する。 例えば, カラムに一定濃度 $C_{0}$ の核種を流量 $q$ で連続注 入し, カラム内が平衡状態になった場合, 非吸着性の核 種では溶液中の濃度は $C_{0}=C_{\mathrm{w}}$, 固相中の濃度は 0 であ る。吸着性の核種では, 溶液中の濃度は $C_{0}=C_{\mathrm{w}}$ で, 固 相中の濃度は $C_{\mathrm{sd}}\left(a_{\mathrm{s}} / M_{\mathrm{s}}\right)$ となり, カラム内では吸着分 の容量が増加する。核種のカラム外への流出および固相 からの核種の脱着がカラム内が平衡に達してから起こる と考えると，両者の核種のカラム内滞留時間はそれぞれ

$$
T_{\mathrm{w}}=a_{\mathrm{w}} / q, \quad T_{\mathrm{t}}=\left(a_{\mathrm{w}}+a_{\mathrm{s}}\right) / q
$$

となる。ゆえに， $R_{f}$ は次式に変換できる。

$$
R_{f}=T_{\mathrm{t}} / T_{\mathrm{w}}=1+a_{\mathrm{s}} / a_{\mathrm{w}}
$$

$a_{\mathrm{s}} / a_{\mathrm{w}}$ を $K d, \rho$ (固相の密度)， $\theta$ (カラム内の間隙率） で表すと次式となる。

$$
\begin{aligned}
a_{\mathrm{s}} / a_{\mathrm{w}} & =\left(M_{\mathrm{s}} / V_{\mathrm{s}}\right) \cdot\left(a_{\mathrm{s}} / M_{\mathrm{s}}\right) \cdot\left(V_{\mathrm{w}} / a_{\mathrm{w}}\right) \cdot\left(V_{\mathrm{s}} / V_{\mathrm{w}}\right) \\
& =\rho \cdot K d \cdot(1-\theta) / \theta \\
\text { ここに, } \rho & =M_{\mathrm{s}} / V_{\mathrm{s}}, K d=C_{\mathrm{sd}} / C_{\mathrm{w}}=\left(a_{\mathrm{s}} / M_{\mathrm{s}}\right) \cdot\left(V_{\mathrm{w}} / a_{\mathrm{w}}\right) \\
\theta & =V_{\mathrm{w}} /\left(V_{\mathrm{w}} / V_{\mathrm{s}}\right) \quad V_{\mathrm{s}}: \text { 固相の体積 }
\end{aligned}
$$

である。これから $R_{f}$ は，

$$
R_{f}=1+\rho \cdot K d \cdot(1-\theta) / \theta
$$

となり， $R_{f}$ と $K d$ が関係付けられる。

この $R_{f}$ から流れが存在する系での $K d$ すなわち $K d_{\mathrm{col}}$ を算出し，バッチ実験で得られた $K d_{\mathrm{bat}}$ と比較検討す る。これらの值は，厳密には分配比（Rd）と表すべき 
ものであるが，本研究では， $K d_{\text {col }}$ および $K d_{\text {bat }}$ と書く ことにする。

\section{2. 岩石試料}

岩石試料は, 茨城県稲田において加熱特性試験等15) を実施した試験坑の破砕帯部および健岩部から採取し た。試験場一帯には, 正長石, 斜長石, 石英, 黒雲母を 主成分とする粗粒黒雲母花崗岩が広く分布する。本花崗 岩体の生成年代は約 6000 万年前, 白亜紀から古第三紀 にかけた時期であるとされている15)。試験坑内の破砕 帯部 $(15 \mathrm{~cm})$ は幅 $1 \mathrm{~mm}$ 程度の白色鉱物を伴い, ハン マーで砂状から細片状に砕ける。破碎帯で採取した破砕 花崗岩の有効間隙率は平均 $3.8 \%$ である。健岩部の花崗 岩は非常に堅硬かつ新鮮なもので, 大塊状を呈し, 割れ 目は良く密着し, その面に沿う風化はない。をた, ハン マー打撃により澄んだ音を出す。この花崗岩の平均的な 物性值は, 一軸圧縮強度 $150 \sim 200 \mathrm{MPa}$, 有効間隙率 $0.7 \sim 1.0 \%$, 密度 $2.6 \mathrm{~g} / \mathrm{cm}^{3}$ である。

採取した岩石試料をジョークラッシャーで粉砕し所定 の粒度に調整した後, 超音波洗浄を行って実験に使用し た。破砕花崗岩の岩石粒は茶褐色に变質し, 表面が粗く 脆い。新鮮な花崗岩は表面が滑らかで堅い。新鮮な花崗 岩石粒および破砕花崗岩石粒の超音波洗浄ならびに未洗 浄の試料についてX 線回折を行ったところ, 破砕花崗 岩石粒の洗浄試料は束沸石を, 未洗浄試料は束沸石打よ びモンモリロナイトを含んでいたが, 新鮮な花崗岩は両 者とも含んでいなかった。また, 偏光顕微鏡観察では, 破砕花崗岩は新鮮な花崗岩に比べて長石類に変質部が認 められ, 全体的に microfissure が卓越している。X 線 回折では破砕花崗岩に束沸石が存在することがわかった が, 鏡下では構成鉱物中には束沸石が認められなかっ た。これは束沸石が破碎帯中の亀裂表面に生成し, 薄片 上に捕えることができなかったためと思われる。

\section{3. 実 験}

3 種類の実験を行った。すなわち， ${ }^{137} \mathrm{Cs}$ を用いたバ ッチ実験, Cs の安定同位体（非放射性核種）を用いた カラム実験, および ${ }^{134} \mathrm{Cs}$ 含有模擬廃棄物ガラス固化体 からの浸出液を使用したカラム実験である。実験に使用 した地下水は, 筑波山の地表下 $250 \mathrm{~m}$ （霞ケ浦用水筑波 1 号トンネル内）から採取したものである。地下水の成 分を表 -1 に示す。以下に, 実験内容, 装置および測定 方法について述べる。

\section{1 バッチ実験}

このバッチ実験では, 岩石粒の粒径および地下水成分
表-1 地下水成分表

単位 $\mathrm{mg} / \mathrm{l}$

\begin{tabular}{l|r|l|r|l|r}
\hline $\mathrm{NH}_{4}$ & $<0.1$ & 全 $\mathrm{Cr}$ & $<0.1$ & $\mathrm{PO}_{4}$ & $<0.5$ \\
$\mathrm{Na}$ & 19.2 & $\mathrm{Ni}$ & $<0.1$ & 全 $\mathrm{Si}$ & 7.0 \\
$\mathrm{~K}$ & 0.7 & $\mathrm{Al}$ & $<0.1$ & 溶存 $\mathrm{Si}$ & 6.9 \\
$\mathrm{Ca}$ & 5.5 & $\mathrm{HCO}_{3}$ & 47.0 & 溶存酸素 & 9.3 \\
$\mathrm{Mg}$ & $<0.1$ & $\mathrm{SO}_{4}$ & 8.3 & $\mathrm{KMnO}_{4}$ ショウヒ & $<5.0$ \\
全 $\mathrm{Fe}$ & $<0.1$ & $\mathrm{Cl}$ & 4.7 & & \\
全 $\mathrm{Mn}$ & $<0.1$ & $\mathrm{NO}_{3}$ & 0.7 & & \\
\hline
\end{tabular}

pH 8.4 導電率 $125 \mu \mathrm{S} / \mathrm{cm} \quad \mathrm{Eh}^{*}+379 \mathrm{mV} \quad \mathrm{pH}^{*} 8.7$ 水温 ${ }^{*} 15.3^{\circ} \mathrm{C}$

*現場計測

の $K d$ への影響について検討し, 破砕花崗岩の吸着特性 を求めた。実験条件は次のとおりである。

岩 石試料：破碎花崗岩および新鮮花崗岩(ともに稲 田産), 超音波洗浄 (純水中) で微粉末 を懸濁しなくなるまで除去した試料およ び末洗浄の試料。

粒径 : $4.0 \sim 6.0 \mathrm{~mm}$ および0.25 0.5 mm

岩石粒重量 : $1.0 \mathrm{~g}$

水 溶 液: 純水製造装置（Millipore製）で製造し た純水 $(\mathrm{pH} 6.8 \sim 7.0)$ および地下水 $(\mathrm{pH}$ 7.8) $30.0 \mathrm{ml}$ に， ${ }^{137} \mathrm{Cs}$ 濃度 が $1.1 \mathrm{ppb}$ $\left(8.0 \times 10^{-9} \mathrm{~mol} / l\right)$ となるように ${ }^{137} \mathrm{CsNO}_{3}$ 溶液を加えたもの。 ${ }^{137} \mathrm{CsNO}_{3}$ 溶液を加 えることによる $\mathrm{pH}$ の変化はなかった。

岩石試料と水溶液をガラス製の三角フラスコに入れ て, 時々振とうしながら所定の期間 7 日，27日，60日， 80 日）経過後, 溶液の $0.5 \mathrm{~m} l$ を採取し, 微粒子等を除 去するために孔径が $0.45 \mu \mathrm{m}$ のフィルター(Millipore製) でろ過した後, ろ液中の ${ }^{137} \mathrm{Cs}$ の $\boldsymbol{\beta}$ 線を $\mathrm{NaI}$ シンチレー ションカウンターで測定した。なお，分画分子量 10000 のフィルター (Millipore製) をも使用してろ過の効果 を比較した結果, 孔径 $0.45 \mu \mathrm{m}$ のフィルターで微粒子が 完全に除去されていることを確認した。

次に，岩石重量と Cs 溶液とを变えた実験を行った。 この条件は, 次項で述べる非放射性セシウムを使用した カラム実験での条件と同じである。

岩石試料：破碎花崗岩および新鮮花崗岩（ともに稲田 産)。試料は, 両者とも超音波洗浄を行っ た後使用した。

粒 径: $4.0 \sim 6.0 \mathrm{~mm}$

岩石重量 : $170 \mathrm{~g}$

水溶液: $\mathrm{CsNO}_{3}$ 水溶液 $(128 \mathrm{~m} l) k^{137} \mathrm{Cs} 2.8 \mu \mathrm{Ci}$ をキャリアとして加えたもの。Cs 濃度は $7.81 \mathrm{ppm}$ であ。 $\mathrm{pH}$ は $0.1 \mathrm{~N} \mathrm{NaOH}$ と $0.1 \mathrm{~N} \mathrm{HCl}$ を使って 6.2 から7.0に調整した。 


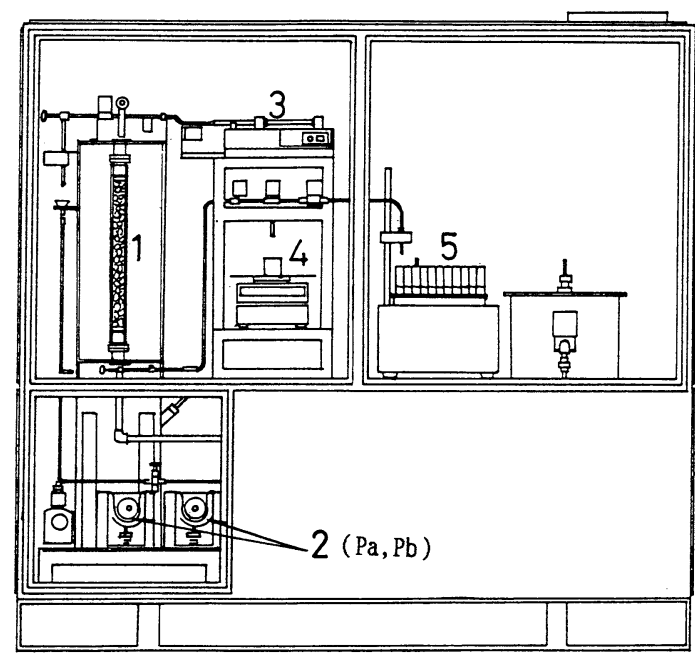

1. カラム 2. ローラーポンプ 3. 瞬間注入器

4. 天びん 5. フラクションコレクター

図-1 カラム実験装置

濃度測定は, $0.1 \mathrm{ml}$ ずつ採取した上澄み液中の ${ }^{137} \mathrm{Cs}$ の放射能を NaI シンチレーションカウンターで測定し た。

\section{2 非放射性セシウムを使用したカラム実験}

本実験の目的の 1 つは, バッチ実験で得られた結果 をカラム実験と比較することである。もう 1 つの目的 は, ホットカラム実験の実験方法の確認および装置の予 備試験である

カラム実験装置の概略を図- 1 に示す。流量制御は， ローラーポンプ $(\mathrm{Pa}, \mathrm{Pb})$ で行った。流量は，それぞ れ $0.01 \sim 0.10 \mathrm{ml} / \mathrm{min}$ および0.10〜 $1.00 \mathrm{ml} / \mathrm{min}$ である。 実験では，目的の流量により $\mathrm{Pa}, \mathrm{Pb}$ を切り替えた。本

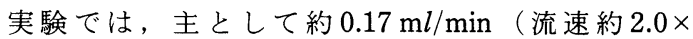
$\left.10^{-5} \mathrm{~m} / \mathrm{s}\right)$ とした。これは岩石試料を採取した試験坑 内の破砕帯中の流速 $\left(2.8 \times 10^{-5} \sim 3.3 \times 10^{-5} \mathrm{~m} / \mathrm{s}\right)^{15)}$ と 同程度である。

岩石試料は, 予め飽和湿潤状態にしてカラムに充填 し，カラム内の空気を抜きながら純水で満たした後，実 験を開始した。

純水に $\mathrm{CsNO}_{3}$ を加え所定の濃度にした溶液をカラム 上部より連続流入させ, カラム下部からの流出液をフラ クションコレクター（20分間隔で採取）で連続採取し, 原子吸光分析器（島津製）で Cs の濃度測定を行った。 以下に，実験条件を示す。

$\begin{array}{ll}\text { 岩石試料 } & : \text { 新鮮花崗岩（稲田産） } \\ \text { 粒径 } & : 4.0 \sim 6.0 \mathrm{~mm} \\ \text { 岩石の比重 } & : 2.62\end{array}$

表 - 2 ガラス形成材および模擬廃棄物の組成

\begin{tabular}{|c|c|c|}
\hline 成分 & 重量比（wt\%） & 使用試薬 \\
\hline \multicolumn{3}{|c|}{ ガラス形成材の組成 } \\
\hline $\mathrm{SiO}_{2}$ & 45.20 & $\mathrm{SiO}_{2}$ \\
\hline $\mathrm{B}_{2} \mathrm{O}_{3}$ & 13.90 & $\mathrm{Na}_{2} \mathrm{~B}_{4} \mathrm{O}_{7}$ \\
\hline $\mathrm{Al}_{2} \mathrm{O}_{3}$ & 4.90 & $\mathrm{Al}(\mathrm{OH})_{3}$ \\
\hline $\mathrm{Na}_{2} \mathrm{O}$ & 9.80 & $\mathrm{Na}_{2} \mathrm{CO}_{3}$ \\
\hline $\mathrm{CaO}$ & 4.00 & $\mathrm{CaCO}_{3}$ \\
\hline $\mathrm{Li}_{2} \mathrm{O}$ & 2.00 & $\mathrm{Li}_{2} \mathrm{CO}_{3}$ \\
\hline $\mathrm{ZnO}$ & 2.50 & $\mathrm{ZnO}$ \\
\hline \multicolumn{3}{|c|}{ 模擬廃棄物の組成 } \\
\hline $\mathrm{SeO}_{2}$ & 0.02 & $\mathrm{SeO}_{2}$ \\
\hline $\mathrm{Rb}_{2} \mathrm{O}$ & 0.12 & $\mathrm{RbNO}_{3}$ \\
\hline $\mathrm{SrO}$ & 0.34 & $\mathrm{Sr}(\mathrm{NO})_{2}$ \\
\hline $\mathrm{Y}_{2} \mathrm{O}_{3}$ & 0.20 & $\mathrm{Y}\left(\mathrm{NO}_{3}\right)_{3} \cdot 6 \mathrm{H}_{2} \mathrm{O}$ \\
\hline $\mathrm{ZrO}_{2}$ & 1.65 & $\mathrm{ZrO}\left(\mathrm{NO}_{3}\right)_{2} \cdot 2 \mathrm{H}_{2} \mathrm{O}$ \\
\hline $\mathrm{MoO}_{3}$ & 1.74 & $\mathrm{H}_{2} \mathrm{MoO}_{4} \cdot \mathrm{H}_{2} \mathrm{O}$ \\
\hline $\mathrm{MnO}_{2}$ & 0.21 & $\mathrm{Mn}\left(\mathrm{NO}_{3}\right)_{2} \cdot 6 \mathrm{H}_{2} \mathrm{O}$ \\
\hline $\mathrm{RuO}_{2}$ & 0.92 & $\mathrm{RuCl}_{3} \cdot 3 \mathrm{H}_{2} \mathrm{O}$ \\
\hline $\mathrm{Ag}_{2} \mathrm{O}$ & 0.03 & $\mathrm{AgNO}_{3}$ \\
\hline $\mathrm{CdO}$ & 0.03 & $\mathrm{Cd}\left(\mathrm{NO}_{3}\right)_{2} \cdot 4 \mathrm{H}_{2} \mathrm{O}$ \\
\hline $\mathrm{SNO}_{2}$ & 0.02 & $\mathrm{SnCl}_{4} \cdot 5 \mathrm{H}_{2} \mathrm{O}$ \\
\hline $\mathrm{Sb}_{2} \mathrm{O}_{3}$ & 0.00 & $\mathrm{SbCl}_{3}$ \\
\hline $\mathrm{TeO}_{2}$ & 0.23 & $\mathrm{TeO}_{2}$ \\
\hline $\mathrm{Cs}_{2} \mathrm{O}$ & 0.98 & $\mathrm{CsNO}_{3}$ \\
\hline $\mathrm{BaO}$ & 0.63 & $\mathrm{Ba}\left(\mathrm{NO}_{3}\right)_{2}$ \\
\hline $\mathrm{La}_{2} \mathrm{O}_{3}$ & 0.51 & $\mathrm{La}\left(\mathrm{NO}_{3}\right)_{3} \cdot 6 \mathrm{H}_{2} \mathrm{O}$ \\
\hline $\mathrm{CeO}_{2}$ & 1.91 & $\mathrm{Ce}\left(\mathrm{NO}_{3}\right)_{3} \cdot 6 \mathrm{H}_{2} \mathrm{O}$ \\
\hline $\mathrm{Pr}_{6} \mathrm{O}_{11}$ & 0.50 & $\operatorname{Pr}\left(\mathrm{NO}_{3}\right)_{3} \cdot 6 \mathrm{H}_{2} \mathrm{O}$ \\
\hline $\mathrm{Nd}_{2} \mathrm{O}_{3}$ & 1.65 & $\mathrm{Nd}\left(\mathrm{NO}_{3}\right)_{3} \cdot 6 \mathrm{H}_{2} \mathrm{O}$ \\
\hline $\mathrm{Sm}_{2} \mathrm{O}_{3}$ & 0.33 & $\mathrm{Sm}\left(\mathrm{NO}_{3}\right)_{3} \cdot 6 \mathrm{H}_{2} \mathrm{O}$ \\
\hline $\mathrm{Eu}_{2} \mathrm{O}_{3}$ & 0.06 & $\mathrm{Eu}\left(\mathrm{NO}_{3}\right)_{3} \cdot 6 \mathrm{H}_{2} \mathrm{O}$ \\
\hline $\mathrm{Gd}_{2} \mathrm{O}_{3}$ & 0.04 & $\mathrm{Gd}\left(\mathrm{NO}_{3}\right)_{3} \cdot 6 \mathrm{H}_{2} \mathrm{O}$ \\
\hline $\mathrm{P}_{2} \mathrm{O}_{5}$ & 0.30 & $\mathrm{H}_{3} \mathrm{PO}_{4}$ \\
\hline $\mathrm{Fe}_{2} \mathrm{O}_{3}$ & 0.70 & $\mathrm{Fe}\left(\mathrm{NO}_{3}\right)_{3} \cdot 9 \mathrm{H}_{2} \mathrm{O}$ \\
\hline $\mathrm{Fe}_{2} \mathrm{O}_{3}$ & 2.20 & $\mathrm{Fe}_{2} \mathrm{O}_{3}$ \\
\hline $\mathrm{Cr}_{2} \mathrm{O}_{3}$ & 0.50 & $\mathrm{Cr}\left(\mathrm{NO}_{3}\right)_{3} \cdot 9 \mathrm{H}_{2} \mathrm{O}$ \\
\hline $\mathrm{NiO}$ & 0.40 & $\mathrm{Ni}\left(\mathrm{NO}_{3}\right)_{2} \cdot 6 \mathrm{H}_{2} \mathrm{O}$ \\
\hline $\mathrm{ZrO}_{2}$ & 1.00 & $\mathrm{ZrO}_{2}$ \\
\hline $\mathrm{Ru}$ & 0.12 & $\mathrm{Ru}$ \\
\hline $\mathrm{Rh}$ & 0.15 & $\mathrm{Rh}$ \\
\hline $\mathrm{Pb}$ & 0.43 & $\mathrm{~Pb}$ \\
\hline 計 & 100.00 & \\
\hline
\end{tabular}

カラム内の間隙率 : 0.50

カラム内の平均密度 : $1.81 \mathrm{~g} / \mathrm{cm}^{3}$

岩石重量 $\quad: 170 \mathrm{~g}$

溶液濃度 $\quad: 10 \mathrm{ppm}\left(\mathrm{Cs}^{+}\right), \mathrm{pH} 7.0$

カラム寸法 : 内径 $1.9 \mathrm{~cm}$, 長さ $47 \mathrm{~cm}$

$3.3{ }^{134} \mathrm{Cs}$ 含有浸出液を使用したカラム実験

高レベル廃棄物ガラス固化体からの浸出液には種々の 
元素が存在する。本実験は，浸出液に含まれるいろいろ なイオンの共存下での Cs の移行特性を評価し, Cs 単 独のコールドカラム実験（3.2項）との比較検討をする ために行った。模擬廃棄物ガラス固化体のガラス形成材 および模擬廃棄物の組成は，それぞれ COGEMA（フラ ンス原子燃料公社）および JW-A（日本原子力研究所） 仕様である。組成を表 -2 に示す。なお，ガラス組成の う ${ }^{134} \mathrm{Cs}$ 以外の核種は，非放射性核種を使用している。

浸出液は, WASTEF (日本原子力研究所, Waste Safety Testing Facility) セル内の浸出液製造装置を用 いて製造した。この浸出液は，ガラス固化体を0.7 $4.0 \mathrm{~mm}$ に粉砕し, 地下水中に室温で140日間浸漬させ て製造したもので，放射能濃度は約 $1 \mathrm{nCi} / \mathrm{ml}, \mathrm{pH}$ は6.4 であった。

(1) カラム内 ${ }^{134} \mathrm{Cs}$ 濃度分布

新鮮（Gf）および破砕（Gc）花崗岩の 2 種類につい て, カラム内の ${ }^{134} \mathrm{Cs}$ 濃度分布を測定した。以下に, 実 験条件を示す。

模擬ガラス固化体：重量 $161.7 \mathrm{~g}$, ${ }^{134} \mathrm{Cs} 0.137 \mathrm{mCi} / \mathrm{g}$-ガラス

浸出液量 : $10.0 l$

実験前の浸出液の放射能濃度 :

$$
\begin{array}{ll}
1.01 \mathrm{nCi} / \mathrm{m} l, & \mathrm{pH} 6.4(\mathrm{Gf}), \\
1.27 \mathrm{nCi} / \mathrm{m} l, & \mathrm{pH} 6.4(\mathrm{Gc})
\end{array}
$$

岩石試料：稲田産花崗岩 $\quad 4.0 \sim 6.0 \mathrm{~mm}$

比 重: Gf 2.59, Gc 2.42
カラム内の間隙率 : Gf 0.49, Gc 0.46 カラム内の平均密度 : Gf $1.81 \mathrm{~g} / \mathrm{cm}^{3}$ Gc $1.77 \mathrm{~g} / \mathrm{cm}^{3}$ 流 量 : Gf $0.176 \mathrm{ml} / \mathrm{min}$ (流速 $2.08 \times 10^{-5} \mathrm{~m} / \mathrm{s}$ ) Gc $0.175 \mathrm{ml} / \mathrm{min}$ (流速 $2.20 \times 10^{-5} \mathrm{~m} / \mathrm{s}$ ) 浸出液の流出時間 : Gf $24.0 \mathrm{~h}, \mathrm{Gc} 43.6 \mathrm{~h}$

カラム中の ${ }^{134} \mathrm{Cs}$ 濃度分布は, 浸出液を流した後力ラ 厶を $1 \mathrm{~cm}$ ずつに切断して自然乾燥させ, そこから岩石 粒を $2 \mathrm{~g}$ 採取し，NaI シンチレーションカウンターを使 用して测定した。

(2) 新鮮な花崗岩に対するカラム流出液中の $\mathrm{Cs}$ と $\mathrm{Sr}$ の濃度分布

流出液中の濃度分布を求める実験は, ${ }^{134} \mathrm{Cs}$ と $\mathrm{Sr}$ に ついて新鮮な花崗岩に対してのみ行った。実験条件は, 前項のカラム内 ${ }^{134} \mathrm{Cs}$ 濃度分布を求めた $\mathrm{Gf}$ と同様で あり，実験装置および流出液の採取方法は，非放射性核 種を用いたカラム実験（3.2項）に準拠した。ただし， 流出時間は, 約385時間（16日間）であった。 $\mathrm{Sr}$ の濃度

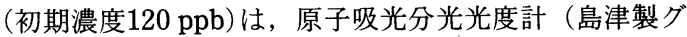
ラファイト炉) で測定した。

\section{4. 実験結果および考察}

\section{1 バッチ実験による ${ }^{137} \mathrm{Cs}$ の花崗岩への吸着}

Cs の花崗岩へのバッチ実験から得られた分配比を表 -3 および図-2 に示す。この結果において, No. 10の 未洗浄試料の $K d_{\mathrm{bat}}$ が高いのは, 岩石試料の項にも述べ たようにモンモリロナイトおよび束沸石が認められるた

\begin{tabular}{|c|c|c|c|c|c|c|c|c|}
\hline \multirow{2}{*}{ 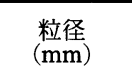 } & \multirow{2}{*}{ 超音波洗浄の有無b) } & \multirow{2}{*}{ 溶媒 } & \multirow{2}{*}{ 実験番号e) } & \multirow{2}{*}{ 試料 } & \multicolumn{4}{|c|}{ 分配比 $R d(\mathrm{~m} l / \mathrm{g})$} \\
\hline & & & & & 7 & 27 & 60 & 80 (Day) \\
\hline \multirow{4}{*}{$4.0 \sim 6.0$} & \multirow{8}{*}{ 洗浄 } & \multirow{2}{*}{ 純 水c) } & 1 & 新鮮 & 60 & 110 & 140 & 130 \\
\hline & & & 2 & 破砕 & 2300 & 6300 & 10000 & 10300 \\
\hline & & \multirow{2}{*}{ 地下水d) } & 3 & 新鮮 & 30 & 50 & 70 & 70 \\
\hline & & & 4 & 破砕 & 440 & 1100 & 2400 & 2100 \\
\hline \multirow{6}{*}{$0.25 \sim 0.50$} & & \multirow{2}{*}{ 純 水(c) } & 5 & 新鮮 & 160 & 240 & 270 & 240 \\
\hline & & & 6 & 破砕 & 2500 & 8800 & 12800 & 12100 \\
\hline & & \multirow{4}{*}{ 地下水 d) } & 7 & 新鮮 & 120 & 160 & 190 & 160 \\
\hline & & & 8 & 破砕 & 1900 & 4400 & 10600 & 9500 \\
\hline & \multirow{2}{*}{ 未 洗 浄 } & & 9 & 新鮮 & 140 & 200 & 240 & 200 \\
\hline & & & 10 & 破砕 & 8100 & 26400 & 47000 & 57900 \\
\hline
\end{tabular}

表 $-3 \quad{ }^{137} \mathrm{Cs}$ の花崗岩に対するバッチ吸着実験の結果a)

a) 固液比は $1: 30$

b）純水中で懸濁しなくなるまで洗浄することにより，粘土鉱物が除去される。

c）純水製造装置（Millipore 製）を使用して製造。

d）霞ケ浦用水筑波 1 号トンネル内（筑波山の地表下 $250 \mathrm{~m} ）$ より採取。成分は表 -1 に示す。

e）図-3 中の番号に一致。 


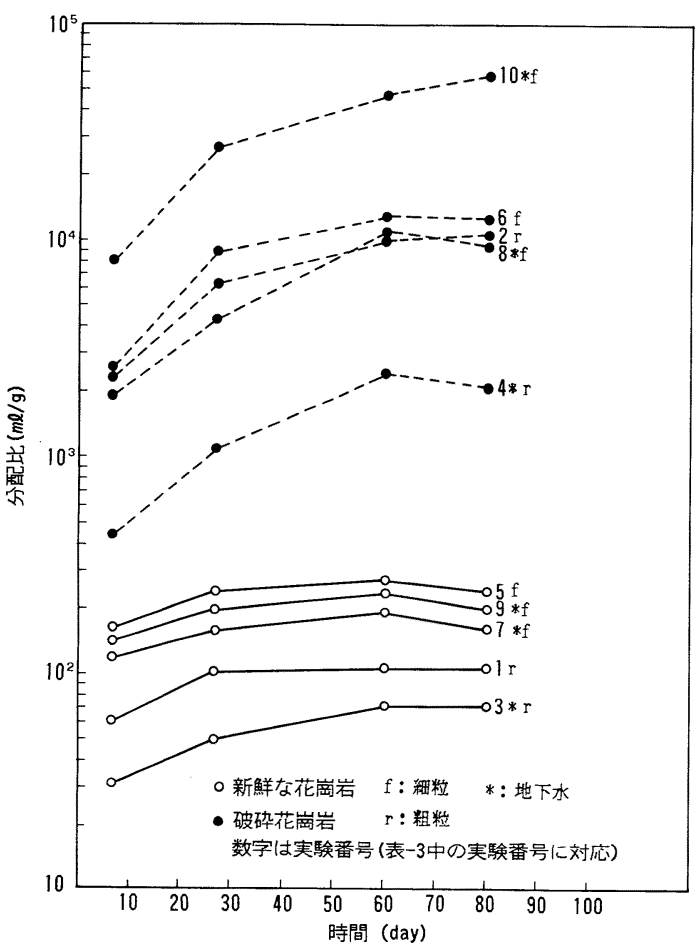

図-2 分配比の時間変化
め,これらに吸着したためと思われる。洗浄して粘土鉱 物を除去した他の破砕花崗岩においても，新鮮な花崗岩 に比較して $K d$ が非常に大きい。洗浄した破砕花崗岩で は, $\mathrm{X}$ 線回折結果 (図-3 参照) では粘土鉱物はないが, 束沸石が認められた。したがって, 洗浄した破砕花崗岩 では，束沸石および長石類の変質部に吸着したと思われ る。これに関しては, 今後さらに検討する必要がある。

No. 3，4，10を除けば新鮮, 破砕花崗岩それぞれにお いて, $K d_{\text {bat }}$ は岩石粒の粒径や液相の種類にほとんど影 響されず，オーダー的にはよく似た值をとるが，表 -4 に示すように，モンモリロナイトおよび沸石の有無によ り $K d_{\text {bat }}$ に差がある。また, 地下水中では, 純水中に比 べて $K d_{\text {bat }}$ No. 3,4のように小さい。これは, 地下水 中の $\mathrm{Na}$ イオンが $19 \mathrm{ppm}$ と高く, Cs は Naイオンと競 合して吸着座を奪われるためであろう7)。また，岩石の 粒径が大きいほど, すなわち比表面積が小さいほど $K d_{\text {bat }}$ が小さいことから, 岩石粒の比表面積から求める 分配係数 $(K a)^{14)}$ も考虑にいれなけれげいけないことを 示唆している。しかし, 比表面積の測定は難しく誤差も 大きいため, 比表面積分配係数を求める実験はあまり行 われていない。ここでは, 固液比を一定にして岩石粒の 単位重量当りの吸着量から求める $K d$ で比較検討した。
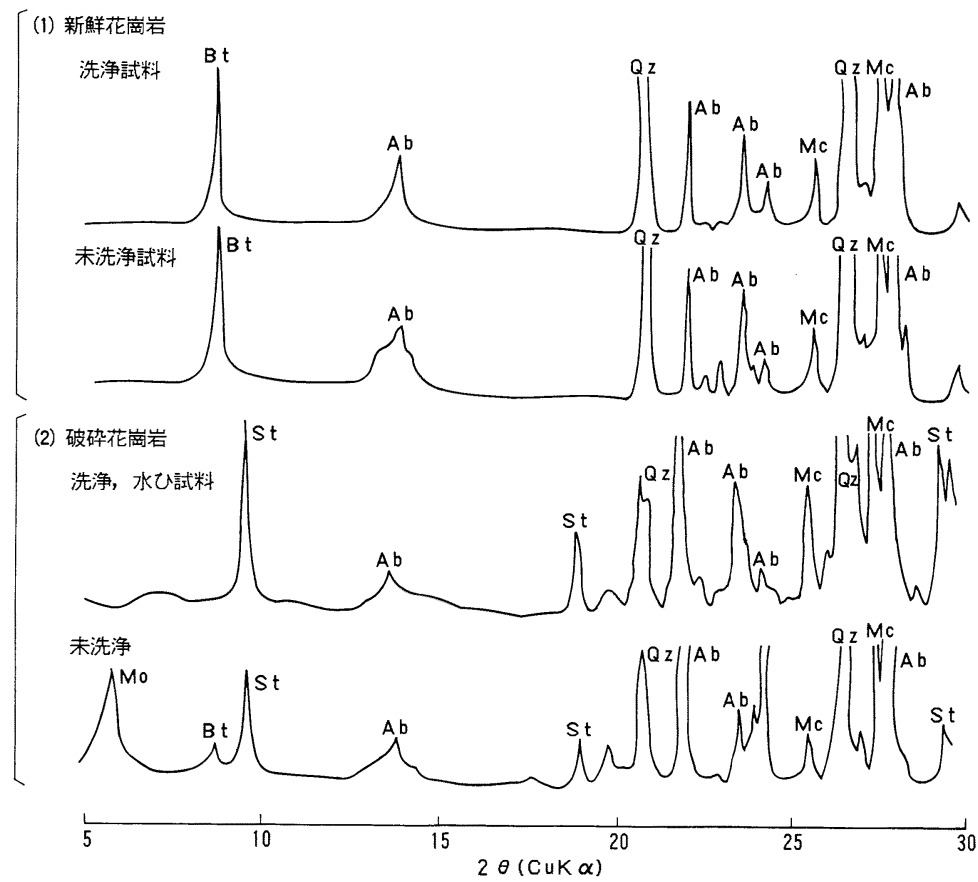

$\mathrm{Qz}$ : 石英 $\mathrm{Ab}$ : 曹長石 $\mathrm{Mc}$ : 微斜長石 $\mathrm{Bt}$ : 黒雲母 Mo：モンモリロナイト St : 束沸石

図-3 X 線回折結果 
表 -4 花崗岩の吸着特性の比較

\begin{tabular}{|c|c|c|c|c|c|c|}
\hline 試 & 料 & モンモリロナイトの有無 & 沸石の有無 & 粒径の大小 & 溶媒の種類 & 60 日 $K d_{\text {bat }}$ \\
\hline \multirow[b]{4}{*}{ 洗 } & \multirow{4}{*}{ 新鮮 } & $x$ & $x$ & 大 & 純 水 & 140 \\
\hline & & $x$ & $x$ & 大 & 地下水 & 70 \\
\hline & & $\times$ & $x$ & 小 & 純 水 & 270 \\
\hline & & $\times$ & $x$ & 小 & 地下水 & 190 \\
\hline \multirow[t]{4}{*}{ 浄 } & \multirow{4}{*}{ 破砕 } & $x$ & 0 & 大 & 純 水 & 10,000 \\
\hline & & $\times$ & 0 & 大 & 地下水 & 2,400 \\
\hline & & $\times$ & 0 & 小 & 純 水 & 12,800 \\
\hline & & $\times$ & 0 & 小 & 地下水 & 10,600 \\
\hline \multirow{2}{*}{$\begin{array}{l}\text { 未 } \\
\text { 洗 } \\
\text { 浄 }\end{array}$} & 新鮮 & $\times$ & $x$ & 小 & 地下水 & 240 \\
\hline & 破砕 & 0 & $\bigcirc$ & 小 & 地下水 & 47,000 \\
\hline
\end{tabular}

バッチ実験で破砕花崗岩の核種保持能力が高いことがわ かったが，次にこれをカラム実験で確認する。

浸出液を使用したカラム実験の条件は, 以上のバッチ 実験の No. 3,4 の条件に相当する。この条件では $K d_{\text {bat }}$ が最も小さく, 核種移行が他の条件と比較して最も速い と想像できる。

\section{2 カラム実験による花崗岩の核種移行特性}

カラム実験から得られる Breakthrough Curve を移流

・分散を考慮した一次元核種移行方程式でフィットする ことにより，遅延係数 $\left(R_{f}\right)$ と分散係数 $(D)$ を求める ことができる。この $R_{f}$ から（1）式により $K d_{\mathrm{col}}$ を算 出し, $K d_{\text {bat }}$ と比較する。

今回の実験に用いた溶液の $\mathrm{Cs}$ 濃度範囲では $D, R_{f}$ は

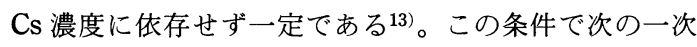
元核種移行方程式を解く。

$$
\begin{aligned}
& \frac{\partial C}{\partial t}=\frac{D}{R_{f}} \frac{\partial^{2} C}{\partial x^{2}}-\frac{v}{R_{f}} \frac{\partial C}{\partial x} \\
& t \leqq 0, \quad x \geqq 0, \quad C=0 \\
& t>0, \quad x=0, \quad C=C_{0} \\
& t>0, \quad x=\infty, \quad C=0
\end{aligned}
$$

ここに, $C$ : 液相中の $\mathrm{Cs}$ 濃度 $v:$ 溶液の平均流速 $C_{0}: \mathrm{Cs}$ 溶液の初期濃度

（2）式の解は (4) 式となる17)。

$$
\begin{aligned}
C / C_{0}= & 1 / 2 \operatorname{erfc}\left\{\left(x-v t / R_{f}\right), /\left(2 \sqrt{D t / R_{f}}\right)\right\} \\
& +1 / 2 \exp (v x / D) \operatorname{erfc}\left\{\left(x+v t / R_{f}\right)\right. \\
& \left./ 2 \sqrt{D t / R_{f}}\right\}
\end{aligned}
$$

ここに, $x$ : カラムの流入端からの距離 $t$ : 流出時間 (4) 式の $C, C_{0}, x, v, t$ に值を与え, $R_{f}, D$ を少しず

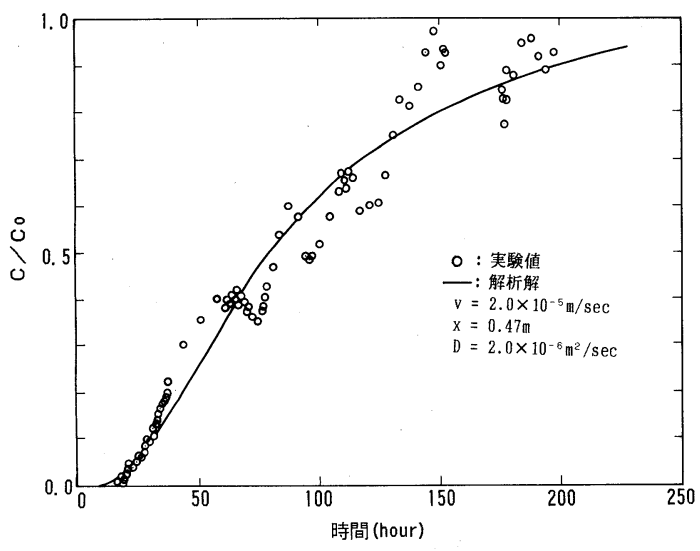

図-4 $\mathrm{Cs}^{+}$の新鮮花崗岩に対する Breakthrough Curve

つ変化させて最小二乗法により $R_{f}, D$ を決定した。この $R_{f}$ を（1）式に与え，流れがある系での $K d$ すなわち $K d_{\text {col }}$ を求めた。このようにして得られた各実験結果を 表 -5 に示す。

\subsection{1 非放射性セシウムを使用したカラム実験}

実験結果を図 -4 に示す。図中の実線は（4）式を適 用して求めた Breakthrough Curve であり，この結果を 表 -5 のコールドカラム法の項に示す。ここで得られた $K d_{\text {col }}(3 \mathrm{ml} / \mathrm{g})$ とバッチ実験から得られた $K d_{\text {bat }}(60 \sim$ $140 \mathrm{ml} / \mathrm{g})$ を比較すると，1〜2 オーダーの差がある。

\subsection{2 浸出液を使用したカラム実験}

新鮮な花崗岩についてカラム内および流出液中の ${ }^{134} \mathrm{Cs}$ と $\mathrm{Sr}$ U)濃度分伂を(4) 式に適用した。破砕花 崗岩については, カラム内濃度分布のみを（4）式に 適用した。ただし，カラム内濃度分布に関しては，吸着 量が最も大きい区間を吸着が平衡に達していると仮定 し, 吸着した ${ }^{134} \mathrm{Cs}$ の吸着量を $S$ とすれば $S=K d_{\mathrm{Cs}} \cdot C$ 
表 - 5 各試験法から得られた結果

\begin{tabular}{|c|c|c|c|c|c|c|c|}
\hline & 験 方 法 & 岩石粒試料 & & $\zeta d(\mathrm{~m} l / \mathrm{g})$ & $R_{f}$ & \multicolumn{2}{|c|}{$D\left(\mathrm{~m}^{2} / \mathrm{s}\right)$} \\
\hline & \multirow{2}{*}{ ッ チ 法 } & 新鮮花崗岩 & $26^{\mathrm{a})}$ & $70^{\mathrm{b})} \sim 140^{\mathrm{c})}$ & - & \multicolumn{2}{|l|}{ - } \\
\hline & & 破砕花崗岩 & $220^{\mathrm{a})}$ & $2,400^{\mathrm{b})} \sim 10,000^{\mathrm{c})}$ & - & \multicolumn{2}{|l|}{ - } \\
\hline \multicolumn{2}{|c|}{ コールドカラム法 } & 新鮮花崗岩 & & 3.0 & 8.0 & 2.0 & $\left(\times 10^{-6}\right)$ \\
\hline \multirow{3}{*}{$\begin{array}{l}\text { ホット } \\
\text { カラム法 }\end{array}$} & \multirow{2}{*}{ カラム内濃度分布 } & 新鮮花崗岩 & & 4.7 & 13.6 & $2.0^{\mathrm{d})}$ & $\left(\times 10^{-6}\right)$ \\
\hline & & 破砕花崗岩 & & 27.5 & 80.0 & $0.1^{\mathrm{e})}$ & $\left(\times 10^{-6}\right)$ \\
\hline & カラム流出液濃度分布 & 新鮮花崗岩 & & 4.2 & 12.0 & 2.0 & $\left(\times 10^{-6}\right)$ \\
\hline
\end{tabular}
b）地下水中（接触時間60日間 固液比 $1: 30$ )
c）純水中（接触時間60日間 固液比 $1: 30$ )
d) $D$ を $2 \times 10^{-6} \mathrm{~m}^{2} / \mathrm{s}$ に固定
e) best fitさせて得られた値

a）非放射性セシウムを使用（接触時間 5 日間 固液比 $1: 0.75$

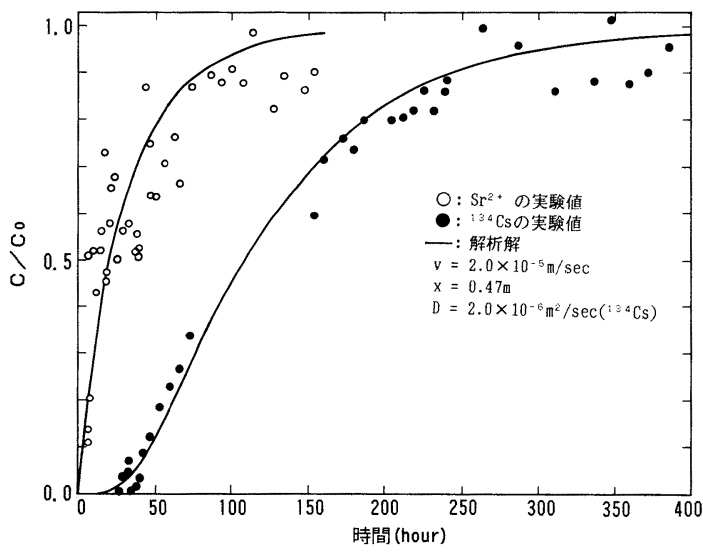

図-5 ${ }^{134} \mathrm{Cs}, \mathrm{Sr}^{2+}$ の新鮮花崗岩に対する Breakthrough Curve

$(C$ : カラム内の溶液濃度) として解析を行った。（0１ $\mathrm{cm}$ 区間は, mechanicalな問題で吸着量が小さいと思わ れるため，1〜2 cm 区間の吸着量の値で正規化を行っ た。）以下に， ${ }^{134} \mathrm{Cs}$ および $\mathrm{Sr}$ のカラム実験の結果につ いて述べる。

${ }^{134} \mathrm{Cs}$ および $\mathrm{Sr}$ の力ラム実験結果を図 -5 に示す。図 中の実線は，(4) 式を適用して求めた Breakthrough Curve である。それから得られた Cs の $R_{f}, D$ の值を表 -5 に示す。 ${ }^{134} \mathrm{Cs}$ の実験データと Breakthrough Curve はよく一致している。本実験での条件はコールドカラム 実験での条件と同じである。Cs の分散係数 $(D)$ の值は $2 \times 10^{-6} \mathrm{~m}^{2} / \mathrm{s}$ となり，これはコールドカラム実験から 得られた $D$ の值に等しく，再現性が認められた。ま た， $R_{f}$ もほぼ等しい值となった。 $\mathrm{Sr}$ の $D$ 值は $1.0 \times$ $10^{-5} \mathrm{~m}^{2} / \mathrm{s}$ となり, ${ }^{134} \mathrm{Cs}$ と比較すると大きい。また, $\mathrm{Sr}$ の $R_{f}$ は1.3で, これはほとんど吸着していないこと

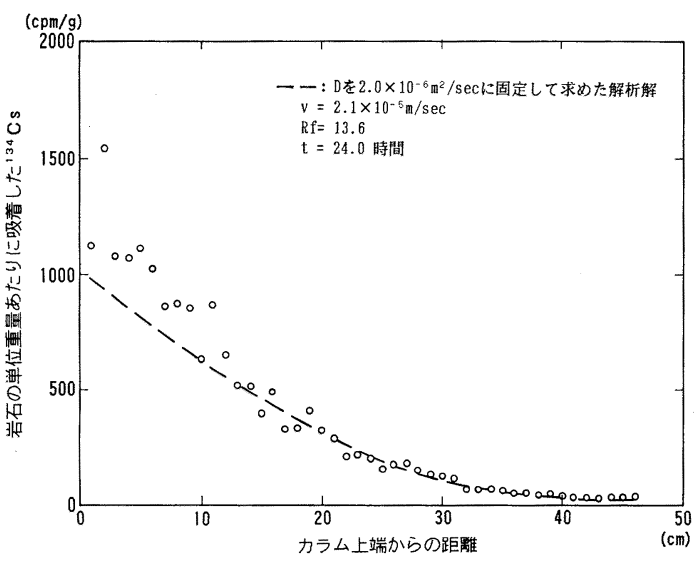

図-6 新鮮花崗岩石粒を充填したカラム内での ${ }^{134} \mathrm{Cs} の$ 濃度分布

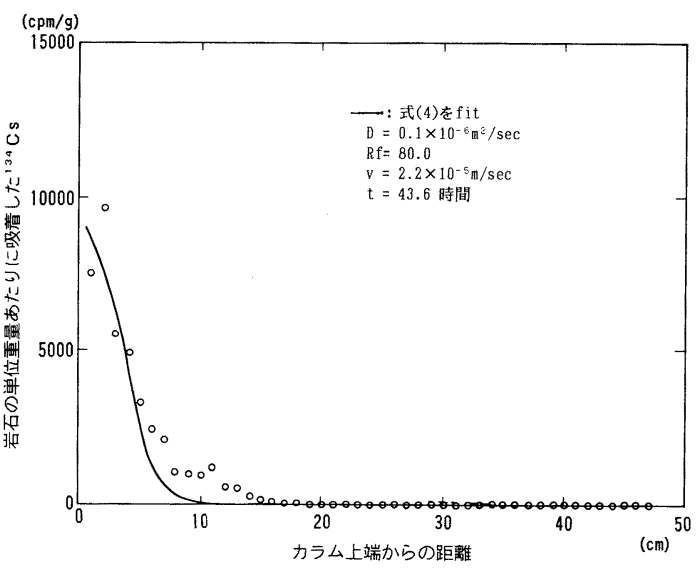

図-7 破砕花崗岩石粒を充填したカラム内での ${ }^{134} \mathrm{Cs}$ の 濃度分布

を示している。Sr では測定誤差が大きいため,これら の値は参考値にとどめておく。

図-6,7 にそれぞれ新鮮な花崗岩と破砕花崗岩に対す る $^{134} \mathrm{Cs}$ のカラム内濃度分布および解析結果を示す。破 線は， $D$ をつの Breakthrough Curve（図-4および 図－5）から得られた $2.0 \times 10^{-6} \mathrm{~m}^{2} / \mathrm{s}$ (表 -5 参照) に固 
定し， $R_{f}$ のみを変数として誤差が最小になる曲線を求 めた。実線は best fitting である。

図-6の新鮮な花崗岩は, 実験值に良く一致してい る。図-7 の破砕花崗岩では, カラム上部より約 $10 \mathrm{~cm}$ の区間内に吸着している。解析解は, 新鮮な花崗岩の実 験と粒度・流速などが同一であるので，当初 $D$ を $2.0 \times$ $10^{-6} \mathrm{~m}^{2} / \mathrm{sec}$ に固定して解析を試みたが，実験值との誤 差が大きいため， $D$ を变数として解析を行った。 $D$ が $1.0 \times 10^{-7} \mathrm{~m}^{2} / \mathrm{s}$ と小さい值が得られたが，原因は不明で ある。

以上のカラム実験結果を考察すると，バッチ実験から 求められた $K d_{\mathrm{bat}}$ に比べて，カラム実験から得られた $K d_{\mathrm{col}}$ は小さい值となった。これは，固・液相間の濃度 平衡が瞬間的に達成されていないためと考えられる しかしながら新鮮花崗岩では，カラム実験值と瞬時平衡 を仮定した一次元核種移行方程式を使用して求めた解析 值とは良く一致している。

\section{5. まとめ}

本実験結果から，Csの核種移行特性について次のよ うな知見が得られた。

（1）バッチ実験によれば，破砕帯を形成する岩石は新鮮 な岩石よりも分配係数が 1 2 オーダー大きくなる。 これは，モンモリロナイトおよび束沸石などの吸着容 量の大きな鉱物に起因していると思われる。破砕帯で は周辺岩盤に比べて地下水の流速が速く，遅延効果が ないように思われがちだが，分配係数は新鮮な花崗岩 よりも大きいので遅延効果が周辺岩盤よりもあること がわかった。

（2）非放射性核種を使用したカラム実験および浸出液を 使用したカラム実験において，新鮮な花崗岩に対して は，流出液中およびカラム中の Cs の濃度分布は，と もに吸着に瞬時平衡を仮定した一次元核種移行方程式 で記述できることにより，新鮮花崗岩に対するCsの 吸着は瞬時平衡を仮定してもよいことがわかった。

破砕花崗岩中の Cs の移行は，吸着に瞬時平衡を仮 定した一次元核種移行方程式では予測できないことが わかった。

今後の研究課題としては, 破砕花崗岩は二次鉱物の生 成により吸着特性が新鮮な花崗岩とは異なることから， 吸着速度の異なる複数のサイトが存在する可能性などを 考慮した解析について検討する必要がある。

また，種々の条件が異なる破砕帯の試料を使用した実 験とその吸着機構の解明および流速が比較的速い場合の カラム実験方法を検討すること，さらに，破砕帯の割れ
目面を持つ岩石コアを使用したシングルフラクチャーモ デルでの実験が必要であると考えられる。

\section{参考文献}

1) SRIDHAR, KOMARNENI and RUSTUM, ROY (1982): Tailormade mixtures of zeolites and clays, Scientific Basic for Nuclear Waste Management II, pp. 411-418.

2) 武部慎一, 山本忠利, 和達嘉樹 (1982): 通気砂層中にお ける放射性核種の移動と分布（I ），保健物理， 17, pp. 437-442.

3）大貫敏彦, 和達嘉樹 (1983): 砂層中における Cs-137 の移 動, 日本原子力学会誌, Vol. 25, No. 6, pp. 74-81.

4) H. R. FUENTES, et al. (1985): Nonequilibrium sorptive behavior of cobalt, cesium and strontium on Banddelier Tuff: Experiments and Analysis, Waste Management' 85, Vol. 3, pp. 175-181.

5) MANSON BENEDICT, et al. (1984)：清瀬量平訳, 原子 力化学工学 第 $\mathrm{N}$ 分冊, 燃料再処理と放射性廃棄物管理の 化学工学, 日刊工業新聞社.

6) 筒井天尊, 西牧研壮 (1975): 放射性廃棄物地中処分の安 全性の評価に関する研究 (I ), 保健物理, 10, pp. 79-86.

7) 筒井天尊, 西牧研壮 (1975): 放射性廃棄物地中処分の安 全性の評価に関する研究（II）, 保健物理, 10, pp. 203210.

8）福井正美, 桂山孝典（1978）: 飽和砂層内における放射性 核種の挙動に関する研究（III）, 保健物理, 13, pp. 93101.

9) 山本忠利, 武部慎一, 和達嘉樹 $(1982)$ : 通気層中におけ る放射性核種の挙動, 保健物理, $17, \mathrm{pp} .3-9$.

10）大貫敏彦, 武部慎一, 山本忠利, 和達嘉樹 (1983): 通気 砂層中における ${ }^{85} \mathrm{Sr}$ と ${ }^{137} \mathrm{Cs}$ の移動に及ぼす間隙水の流速 の影響, 保健物理, 18, pp. 11-16.

11）大貫敏彦 他 (1984): 帯水砂層中における放射性核種 $\left({ }^{60} \mathrm{Co},{ }^{85} \mathrm{Sr}\right.$, 抢よび $\left.{ }^{137} \mathrm{Cs}\right)$ の移動, 保健物理, 19 , pp. 1318.

12）山形茂 他 (1981): 花崗岩と水におけるセシウムの分 配係数に関する研究（速報）, JAERI-M 9432 .

13) R. J. SERNE and J. F. RELYEA (1982): The status of radionuclide sorption-desorption studies performed by the WRIT Program, Pacific Northwest Laboratory, PNL3997.

14) OECD NUCLEAR ENERGY AGENCY (1983): Sorption modelling and measurment for nuclear waste disposal studies, Summary of an NEA Workshop.

15）熊田政弘 他（1986）: 花崗岩盤中における原位置試験 JAERI-M 86-044.

16）佐伯誠道編（1984）: 環境放射能，ソフトサイエンス社, pp. $146-177$.

17) JACOB BEAR (1972): Dynamics of fluids in porous media, Chapter 10, Hydrodynamic Dispersion.pp. 579663.

（1990年6月21日受付，1990年11月27日受理） 